\title{
READERS Insight
}

Journal of Management Info (JMI)

ISSN:2313-3376

www.readersinsight.net/jmi

伍

\section{Leverage, ownership structure and firm performance: evidence from Karachi stock exchange}

\author{
Adnan Ali $^{1 *}$, Attaullah Shah ${ }^{2}$ \\ ${ }^{1}$ PhD Student IM Sciences, Assistant Professor, IM Sciences, \\ *Corresponding author: adnanali@aup.edu.pk, attashah15@hotmail.com
}

\begin{abstract}
This study aims to investigate the relationship between the ownership structure and firm performance. The study uses two performance measures i.e. market-based performance measure (Tobin's Q) and accounting-based performance measure (return on assets (ROA)) as dependent variables and ownership proxies and other control variables as independent variables whereas leverage is used as moderating variable. The ownership proxies include the managerial ownership and institutional ownership while the control variables include the size of the firm, the coefficient of variation, and growth. This study has used simple regression analysis while using data of 355 firms listed on Karachi Stock Exchange (KSE) for the years 2003 to 2008. The results show that the ownership structure has significant relationship with the market-based performance measure, while it has insignificant relationship with the accounting-based performance measure. Moreover, the leverage has no moderating effect on the relationship between ownership structure and firm performance.
\end{abstract}

Keywords: Tobin's Q; Ownership; Return on Assets; Firm Performance; Leverage; Karachi Stock Exchange;

\section{Introduction}

All businesses need finance for working capital and capital expenditures. To serve this purpose corporations use either debt or equity financing. It depends upon the structure of the organization, size and policies of the organization to take decision whether to select equity or debt or both in the financial structure of the firm. In short capital structure is the combination of common equity, preferred equity and the liabilities (long and short term) of a firm. Proper management of capital structure for firm financing is very important because it helps to shape the financial position of the organization. The topic capital structure got on screen late in the 1950s by the work of Modigliani and Miller (1958) and is still debatable (Chakraborty, 2010; Karadeniz et al, 2009). Nevertheless, the concept of capital structure got importance after the famous work done by Miller and Modigliani, (1958). In their famous theory "theory of irrelevancy of capital structure" it was postulated that firm performance is independent of its capital structure in the perfect capital market. However, later they argued that this relationship can be changed due to debt as it offers tax advantage (Modigliani and Miller, 1963). In recent times, in the literature of corporate finance the capital structure is considered as a major issue (Chakraborty, 2010; Karadeniz et al, 2009).

Berle and Means (1932) initiated the study for the performance of the firm and ownership structure relationship and resulted in inconsistent relationship between the two. Jensen and Meckling (1976) explained this work through the postulation of 'agency theory' by introducing a principal-agent frame work highlighting the agency problem between the management and the stockholders. This agency problem can be minimized by using debt in the capital structure and is used as a disciplining tool to monitor managers of the company (Jensen and Meckling, 1976). Alternatively, this agency cost can also be minimized by using high managerial ownership (Jensen and Meckling, 1976) and greater the ability of inside managerial owners to set debt level according to the interest of the firm (Friend and Lang, 1988). Higher the inside managerial ownership higher the firm performance due to higher the probability that the managers prevent the wastage of resources and firm performance is ensured (smith, 1990).

One thing is very important to mention here and that is that different studies have reported different results for the developed and underdeveloped countries. Many authors reported a linear relationship between both the firm performance and ownership (Berle and Means, 1932; Jensen and Meckling, 1976; Mehran, 1995) while other reported a non-linear relationship (Pushner, 1995; Morck et al., 1988; McConnell and Servaes, 1990 and 1995; Short and Keasey, 1999). Some of the studies showed significant results (Hill and Snell, 1989; McEzchern, 1975) while others reported no significant results (Demstz and Lehn, 1985; Kamerschen, 1968). Loderer and Martin (1997) found no proof that performance is increased by the increased management ownership, while Cho (1998) and Prowse (1999) have reported reverse way causality between the firm performance and management ownership. The ownership structure is used in the study to deal with the agency problem, which may have possible impact on the firm performance as it can be used as a controlling mechanism (Jensen and Meckling, 1976). The managers being given shares in the company would align their interests with that of other shareholders and hence reduce agency costs; this will serves a positive leverage for the performance of the firm. Therefore, a positive association is expected between the performance of the company and the management ownership.

The literature on corporate finance shows that the firm performance and the capital structure have strong association between them. The capital requirement can be fulfilled by three sources i.e. new share 
capital, short term and long term debt and earnings retained by the firm. These three sources can be individually taken or a mix of them and the decision taken must have impact on the firm performance. The introduction of debt in the capital structure can lead to monitor managers and hence improve firm performance (Jensen and Meckling, 1976). At start it was postulated that capital structure have no effect on the firm performance (Modigliani and Miller, 1958). However, later on many commentators strongly suggested that such decision regarding capital mix and making changes in it could have important effect on the performance of the firm in either way (Miller and Modigliani, 1961; Williamson, 1988; Grossman and Hart, 1986; Jensen, 1986; and Stulz, 1990). Many researchers reported different results regarding the association between the firm performance and capital structure. Some found a negative relationship between the two (Booth et al., 2001; Chakraborty, 2010; Huang and Song, 2006; Karadeniz et al., 2009; Rajan and Zingales, 1995) while others found positive association among them (Berger and Bonaccors di Patti, 2006; Frank and Goyal, 2003).

From all the above study it is clear that the use of debt in the capital structure affects a company's performance because companies will usually agree to fixed repayments for a specific period. These payments occur regardless of the firm's performance. Equity financing typically avoids these repayments but may require companies to give an ownership stake in the company to venture capitalists or investors and hence agency problem. Now the question is that, do the relationship of ownership structure on the performance of the firm is affected by the debt in either way.

This study is different and unique of its nature from other studies conducted in Pakistan or any where according to the limited knowledge we have and that is, in most of the literature it is seen that, the focus is either on one of the sector of the economy or either similar variables of a proxy (i.e. capital structure) are taken for a study, which shows that collinearity exists in between. However, there is no measure of co-linearity reported in their studies. Secondly, very few studies have used market based firm performance measure i.e. Tobin's Q and thirdly, no study is available to measure the capital structure and firm performance by taking debt as moderating variable in Pakistan. Our study uses 355 firms listed on Karachi Stock Exchange (KSE) Pakistan for the years 2003 to 2008. The rest of the firms are excluded due to non-availability of data or they may be a component of a financial sector. The study has used Tobin's Q a market-based proxy and return on assets (ROA) an accounting based proxy as dependent variables for measuring firm performance and ownership structure with the low level and high level of debt, taken as a moderating variable. The other control variables are consisted of ownership proxies including the managerial and institutional ownership, the size of the firm, the growth opportunities and the coefficient of variation of net income. The year dummies are used to check the fixed effect and the assumptions of Ordinary Least Square (OLS) are tested.

\section{Problem statement}

To find out the moderating effect of capital structure on the corporate performance in the presence of various ownership structures in all firms listed on Karachi Stock Exchange (KSE) of Pakistan.

\section{Objectives of the study}

To know the moderating effects leverage has on corporate performance.

To know the impact of institutional ownership and director ownership on the firm performance.

How the above relationship is interrelated in higher and lower leverage.

The following part of the paper is organized as: Section 2 will in brief discuss both the theoretical foundation and empirical evidences of the research. In Section 3, the theoretical frame work, the sample and data selection and methodology of the research are discussed. In Section 4 the results and analysis are outlined while at the last Section 5, concludes the research.

\section{Literature review}

This section covers in brief the discussion on both the theoretical foundation and empirical evidences of the relationship between the ownership structure and firm performance and the moderating role of debt on this relationship.

The modern organizations concept keeps stress on the ownership and management separation for a company because in real sense there exists a difference between the interests of the management of the company and those who provide the capital to the company. Berle and Means (1932) who reported a linear relationship between the performance of the firm and the ownership structure first pointed it out. Later, this work was clearly explained by Jensen and Meckling (1976) through the postulation of 'agency theory' by introducing a principal-agent framework highlighting the agency problem between the management and the stockholders. A common perception of the corporate governance models is that those firms having entrenched ownership structures shows high performance due to less agency costs referred to as efficient monitoring hypothesis (Jensen and Meckling, 1976). Moreover, the debt can be used as a disciplining tool to monitor managers of the company. Secondly high managerial ownership could lead to decrease the agency cost (Jensen and Meckling, 1976) and less the conflicts with the stockholders and greater the ability of inside managerial owners to set debt level according to the interest of the firm (Friend and Lang, 1988) higher the inside managerial ownership higher the firm performance because higher the probability that the managers prevent the wastage of resources and firm performance is ensured (smith, 1990). In disparity, (Demsetz, 1983; Fama and Jensen, 1983; Morck et al., 1988; Pedersen and Thomsen, 2003) pointed out that increase in managerial ownership could lead to managerial entrenchment and hence managerial opportunism. However, such entrenchment may lead to expropriation of minority shareholders interests (Shleifer, Andrei and Vishny, 1997; Mustafa, 2011).

The relationship between the firm performance and capital structure was first postulated by Modigliani and Miller (1958) who reported that there is no relationship between the two under the perfect market conditions. However, later it was reported that performance of the firms is determined by the capital structure (Hirshleifer, 1966; Modigliani and Miller, 1963; and Robichek and Myers, 1966) by considering the taxes and bankruptcy costs while determining the optimal capital structure. There is a mix of results available on the between the relationship of performance of the firm and the capital structure. Some authors reported positive relationship between the performance of the firm and the capital structure (Abor, 2005; Berger and Bonaccorsi di Patti, 2006; Roden and Lewellen, 1995). On the other hand, some researchers found a negative relationship between the firm performance and capital structure (Chakraborty, 2010; Booth et al., 2001; Huang and Song, 2006; Friend and Lang, 1988; Karadeniz et al., 2009; Rajan and Zingales, 1995; Titman and Wessels, 1988; Wald, 1999). Several other studies showed weak or no statistical relationship between the performance of the firm and the capital structure (Ebaid, 2009; Tang and Jang, 2007).

The link between the firm performance and the corporate governance is underpinned by the relationship between the ownership structure and the capital structure. The ownership structure consisted of the family ownership, institutional ownership, managerial ownership and larger external shareholder or block holder and small scattered individual ownership. The managerial entrenchment or opportunism can be reduced by external block-holders which will result in low agency conflicts that exists directly between the inside managers and the stockholders (Shleifer and Vishny, 1986). In this case the large external block holders will prefer high debt ratios below the bankruptcy point as these higher debt ratios can serve as monitoring tool. Driffield et al. (2006) reported a non-linear relationship between managerial ownership and leverage. When there is less managerial ownership the agency conflict is decreased leading to higher debt level and in contrast if there is increase managerial ownership it would direct the managerial opportunism and hence lower debt. Friend and Hasbrouck (1988) and Friend and Lang (1988) reported a 
negative relationship between the leverage and management ownership as increased management ownership reduces the debt level of the firm in order to reduce default risk.

Myers (1984) presented two theories regarding optimal capital structure i.e. one is called as the static tradeoff theory while second one is called as "pecking order theory". The static trade-off theory states that, a firm can obtain optimal capital structure by accomplishing a balance or equality between the benefits and the financial distress costs. The benefits are in form of interest-tax shields and the costs are in two forms i.e. agency costs and bankruptcy costs. The static trade off theory is assumed to have a positive relationship between the capital structure and firm performance (Chakraborty, 2010; Fama and French, 2002; Karadeniz et al., 2009; Myers and Majluf, 1984; Myers, 1984). The Pecking order theory states that, there exists no optimal capital structure for a firm, and there exists asymmetrical information between the managers and the shareholders. Therefore in order to reduce this problem of asymmetrical information the companies favor to finance company's operations through internal sources that is retained earnings at the first instance which is at the same time least costly, then they prefer to use debt and as a last choice they use equity financing, which is considered as the most costly one. This theory claims a negative relationship between the capital structure of the firm and firm performance.

\section{Pakistani context}

There is exactly no such study conducted in Pakistan according to the limited knowledge of the authors; however these sectoral studies have made contribution to the literature of corporate finance in other aspects. Ghafoor (2012) while studying the engineering sector of Pakistan reported the existence of significant but negative relationship between the total debt and performance of the firm that is measured by Tobin's Q and ROA. The same is also supported by Memon et al, (2012) who reported a negative relationship between the debt and the accounting-based performance measure (ROA). Siddiqui and Shoaib (2011) have used Tobin's Q as a measure of firm performance and their results show that the leverage does not affect the performance of the banks. The results reported by Amjed (2011) are different to other investigations on capital structure which shows a significant but negative relationship between the company's performance and the leverage.

\section{Framework and methodology}

\section{Theoretical framework}

In this Section, the theoretical framework, the sample and data selection and methodology of the research are discussed. The study uses two performance measures i.e. market based performance measure, the Tobin's $\mathrm{Q}$ and the accounting-based performance measure, the return on assets (ROA), both as the dependent variables and the independent variables include the ownership proxies and other control variables, whereas leverage is used as moderating variable. The ownership proxies include the managerial ownership and institutional ownership while the control variables include the size of the firm, the coefficient of variation of net income, and growth.

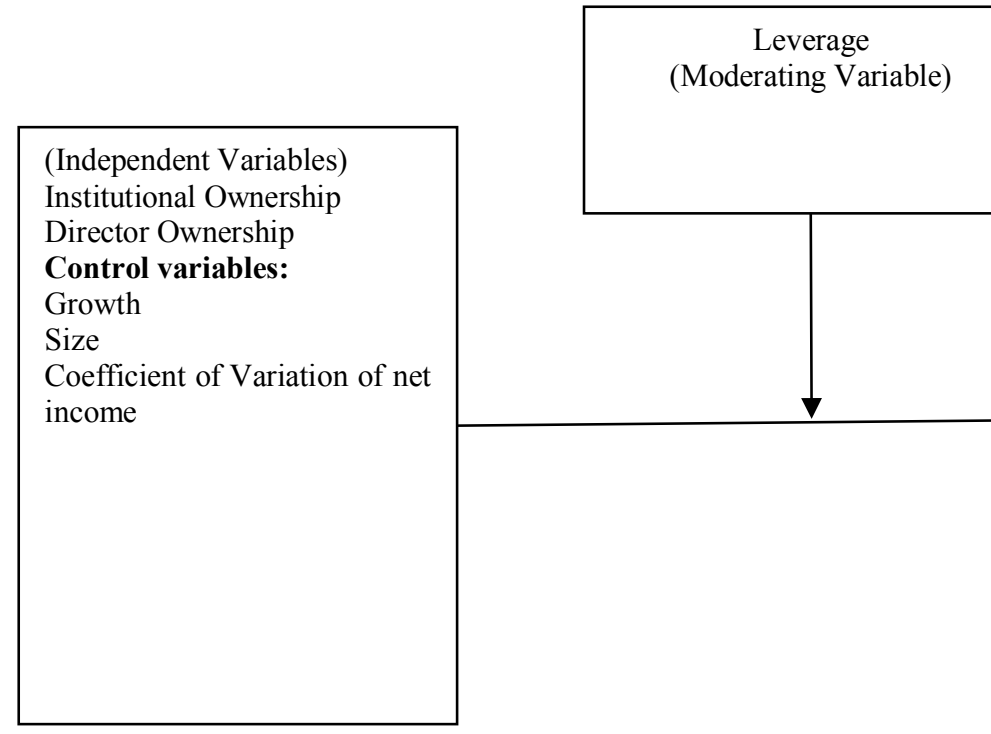

\section{Sample}

The sample consists of 355 firms listed on the Karachi Stock Exchange (KSE). The data is taken from KSE for the period of 06 years (2003 to 2008). The unusual or influential data containing outliers i.e. the extreme values were removed (below 1-percentile and above $99^{\text {th }}$ percentile). These outliers were removed through cook's D criterion as if Crook's D is greater than 2squart $(\mathrm{k} / \mathrm{n})$ then such observations are said to be influential data. Where $\mathrm{k}$ is the no. variables and $\mathrm{n}$ is the no. of observations. In this study the financial firms and the firms lacking the availability of data have been excluded. Fixed effect model has been run by taking year dummies and Breush Pagan / Cook-Weisberg test is used for the removal of heteroskedascity.

\section{Model}

This study has used regression analysis by taking data of 355 firms listed on Karachi Stock Exchange (KSE) for the years 2003 to 2008. The data is taken from KSE for the period of 06 years (2003 to 2008). This study has used Tobin's Q and ROA as proxies of dependent variables for measuring the relationship between the firm performance and ownership structure in the presence of the low level $(<0.629)$ and high level of debt $(>0.629)$, taken as a moderating variable. The other control variables are consisted of ownership proxies including the managerial and institutional ownership, the size of the firm, the growth opportunities and the coefficient of variation. The regression models are as under;

FP $(Q)=\beta 0+\beta_{1}$ Directors $+\beta_{2}$ Insti $+\beta_{3}$ Size $+\beta_{4} \mathrm{CV}+\beta_{5}$ Growth $+\varepsilon$ FP $($ ROA $)=\beta 0+\beta_{1}$ Directors $+\beta_{2}$ Insti $+\beta_{3}$ Size $+\beta_{4} C V+\beta_{5}$ Growth $+\varepsilon$

The above equations are estimated twice, first for firms with leverage below the median value, and then for firms with value above the median.

Where:

FP is the firm performance which consists of market based proxy Tobin's "Q" to measure firm performance and return on assets (ROA) as an accounting based proxy for measuring firm performance, and both are taken as dependent variables. The ROA is equal to the net income divided by the total assets while the Tobin's $\mathrm{Q}$ is equal to (Book value of Debt + Market value of equity) / (Book value of debt + Book value of equity).

Directors represent the percentage management shareholdings in the equity capital of the firm. It is focused for this study because it plays a vital role in reducing the agency problem between the principal and the agents. The inside managerial ownership avoids debt in the capital structure in order to reduce the bankruptcy tension.

DTA represents the debt to assets ratio or the leverage of the company. 
Insti means percentage ownership of institutional shareholders. It represents the institutional shareholdings is the firm.

Size represents the size of the firm. It is taken as log of assets.

Growth it represents the geometric mean of annual percentage increase in assets.

$\mathrm{CV}$ is the coefficient of variation of net income. It shows the standard deviation of net income / mean of net income.

\section{Results and discussion}

The results and discussion include the descriptive statistics and matrix correlation and also the regression of the firm performance. The regression is estimated two times both for Tobin's Q and ROA under two conditions i.e. when the debt value is less than the median value of debt (i.e. 0.629) and secondly when it is above the median value (i.e. 0.629).

Table 4.1: Summary Statistics

\begin{tabular}{|rrrrrrl|}
\hline Variable | & Obs & Mean & Std. Dev. & Min & Max \\
\hline Q | & 714 & 1.420629 & 2.271879 & .2142046 & 20.40261 \\
\hline ROA | & 720 & .1002763 & .107432 & -.2347787 & .5696762 \\
\hline size | & 720 & 7.875426 & 1.51028 & 4.102643 & 12.14048 \\
\hline leve | & 720 & .5843923 & .2035517 & .0139018 & .9996254 \\
\hline cv | & 720 & .6573669 & .337332 & .1203245 & 1.5 \\
\hline ggrowth | & 720 & .1596843 & .1115664 & -.0737237 & .5 \\
\hline a_inst | & 720 & .2033194 & .1674523 & 0 & .84 \\
\hline a_direc | & 720 & .2473889 & .2573522 & 0 & .88 \\
\hline
\end{tabular}

Table 4.1 depicts the descriptive statistics of the two dependent variables taken for measuring firm performance i.e. Tobin's $Q$ and ROA and other independent and controlled variables used in the study i.e. size, ownership proxies, coefficient of variation of net income, growth and debt is taken as moderating variable. It shows that the average value of Tobin's Q (1.42) is greater than one which depicts that the market value of listed companies in Karachi Stock Exchange is greater than their book values. Morck, Sheilifer and Vishny (1988) have used Tobin's Q as the measure of firm performance and argue that high value of Tobin's Q refers to the probability to issue more shares in-order to increase revenues and companies assets values. Bond and Cumin (2001) used Q as a bench mark measure of return on investments (ROI) in-order to show the market performance of the firm. The average value of leverage (58\%) shows that the companies under consideration have maximum portion financed with debt as compared to equity. The table also shows that on average the institutional investors and managerial shareholders have $20 \%$ and $24 \%$ ownership respectively.

Table 4.2: Matrix of Correlation

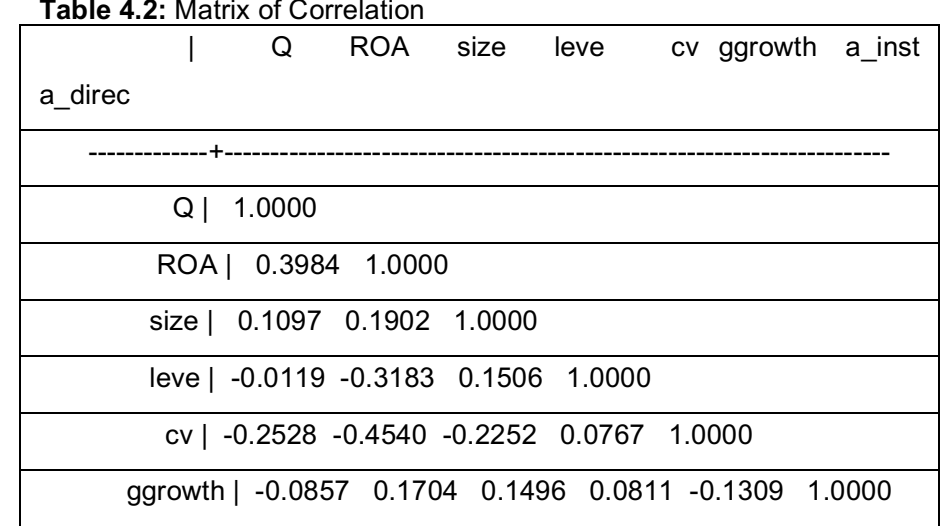

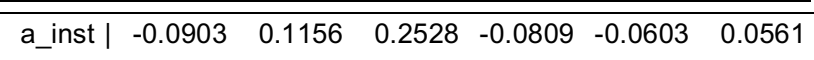
1.0000

a_direc | $-0.1899 \quad-0.2532 \quad-0.3020 \quad 0.1126 \quad 0.0763 \quad 0.0008$ 0.35791 .0000

Table 4.2 is established according to the Pearson correlation matrix and it shows the correlation among the dependent and independent variables. The result depicts that the leverage has got a negative and weak relationship with both the proxy measures of the firm performance i.e. Q (-0.0119) and ROA (-0.3183) but a stronger relationship with ROA as compared to Tobin's Q. The negative relationship between the capital structure and performance of the firm was reported by (Chakraborty, 2010; Booth et al., 2001; Friend and Lang, 1988; Huang and Song, 2006; Karadeniz et al., 2009; Rajan and Zingales, 1995; Titman and Wessels, 1988; Wald, 1999). The institutional ownership show negative correlation with Q (-0.0903) and positive correlation with the ROA (0.1156) and it suggest that it has alternative effect on both the Q and ROA. The results also shows that there is a negative correlation between the managerial ownership and both the proxy measures of the firm performance i.e. Q (-0.1899) and ROA (-0.2532) Berle and Means (1932) found inconsistent relationship between the firm performance and ownership structure.

Table 4.3: Regression Results for Firm Performance in Less Levered Firms Dependent Variable $=$ Tobin's $Q$

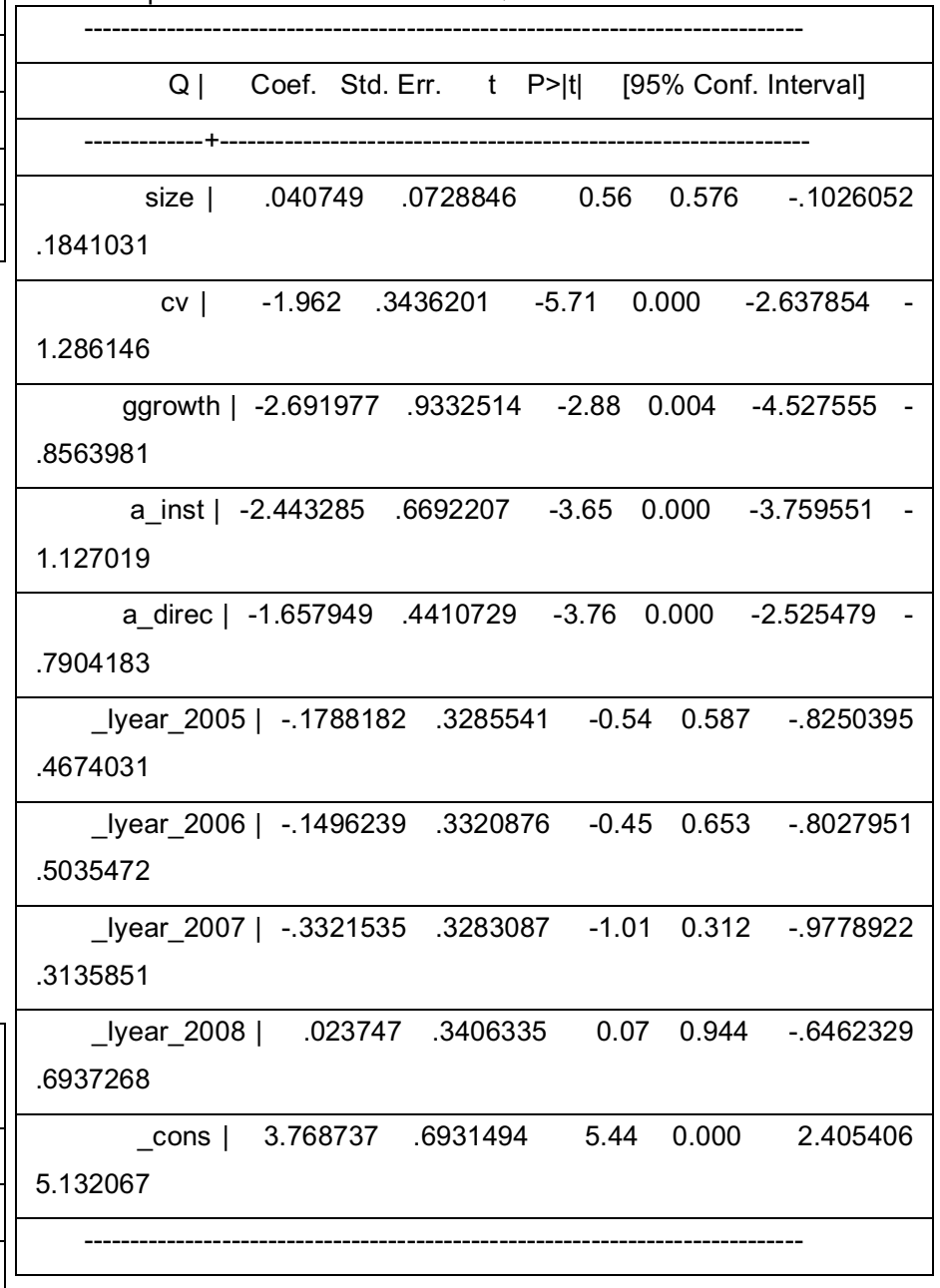

Table 4.3 shows the regression results for measuring firm performance for all those firms for which the leverage value is below the median value $(0.629)$ for the dependent variable Tobin's $Q$. The institutional shareholding has negative and significant relationship with Tobin' Q. The coefficients value are -2.443 , respectively which means that one unit increase in institutional shareholding will reduce 
the firm performance by 2.69 and 2.44 units, respectively. The managerial ownership has negative relationship with firm performance (-1.657) and statistically significant with $\mathrm{P}$ value less than 0.05 which means that one unit increase in managerial ownership will reduce Q by 1.657 units. Some of the studies also showed significant results (Hill and Snell, 1989; McEzchern, 1975).

The $\mathrm{p}$ value for the year dummies is greater than 0.05 which indicates that the intercept of the year 2005, 2006, 2007 and 2008 are insignificantly different than that of the reference year.

The above regression was estimated for all such firms where the leverage ratio was below its median value, i.e. 0.629 , for taking into consideration the dependent variable as Tobin's Q and so a total of 355 observations were included. The same regression was estimated for firms where the leverage ratio was above the median value, results are given below.

Table 4.4: Regression Results for Firm Performance in Highly Levered Firms Dependent Variable $=$ Tobin's $Q$

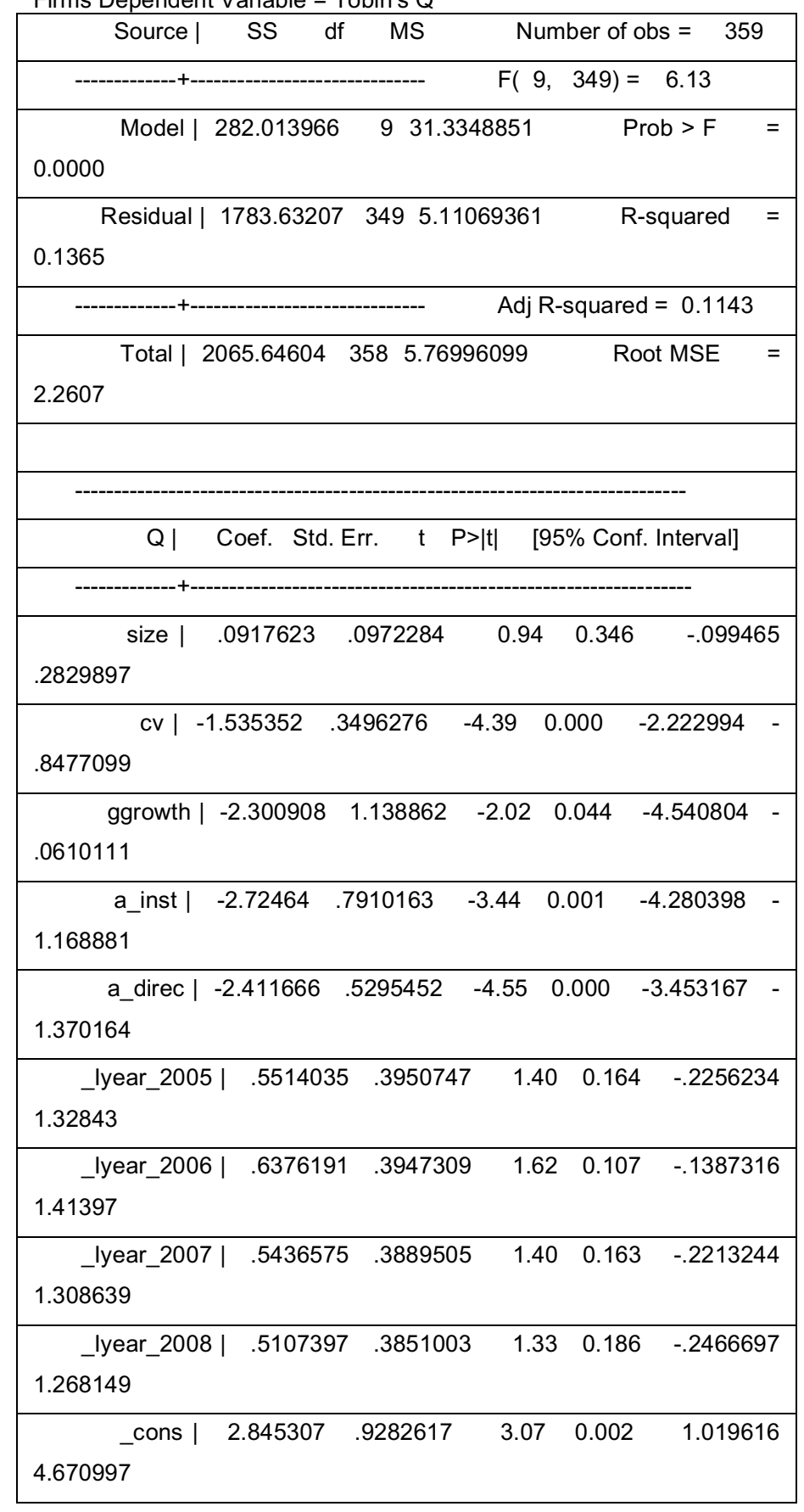

Table 4.4 shows the regression results for measuring firm performance for all those firms for which the leverage value is above the median value (0.629) for the dependent variable Tobin's $Q$. There are 359 no of observations with F-value below 0.05 which shows that the model is overall significant and its R-squared values shows that there is about $13 \%$ chances that the dependent variables is effected by the independent variables under study. The institutional shareholding is statistically significant with P-value less than 0.05 and coefficients value of -2.72 , respectively which means that one unit increase in institutional shareholding will reduce the firm performance by 2.72 units. The managerial ownership has negative relationship with firm performance (-2.411) and statistically significant with $\mathrm{P}$ value less than 0.05 which means that one unit increase in managerial ownership will reduce $\mathrm{Q}$ by 2.411 units.

The $\mathrm{p}$ value for the time dummies is greater than 0.05 which indicates that the intercept of the year 2005, 2006, 2007 and 2008 are insignificantly different than that of the reference year.

Table 4.5: Regression Results for Firm Performance in Less Levered Firms Dependent Variable $=$ ROA

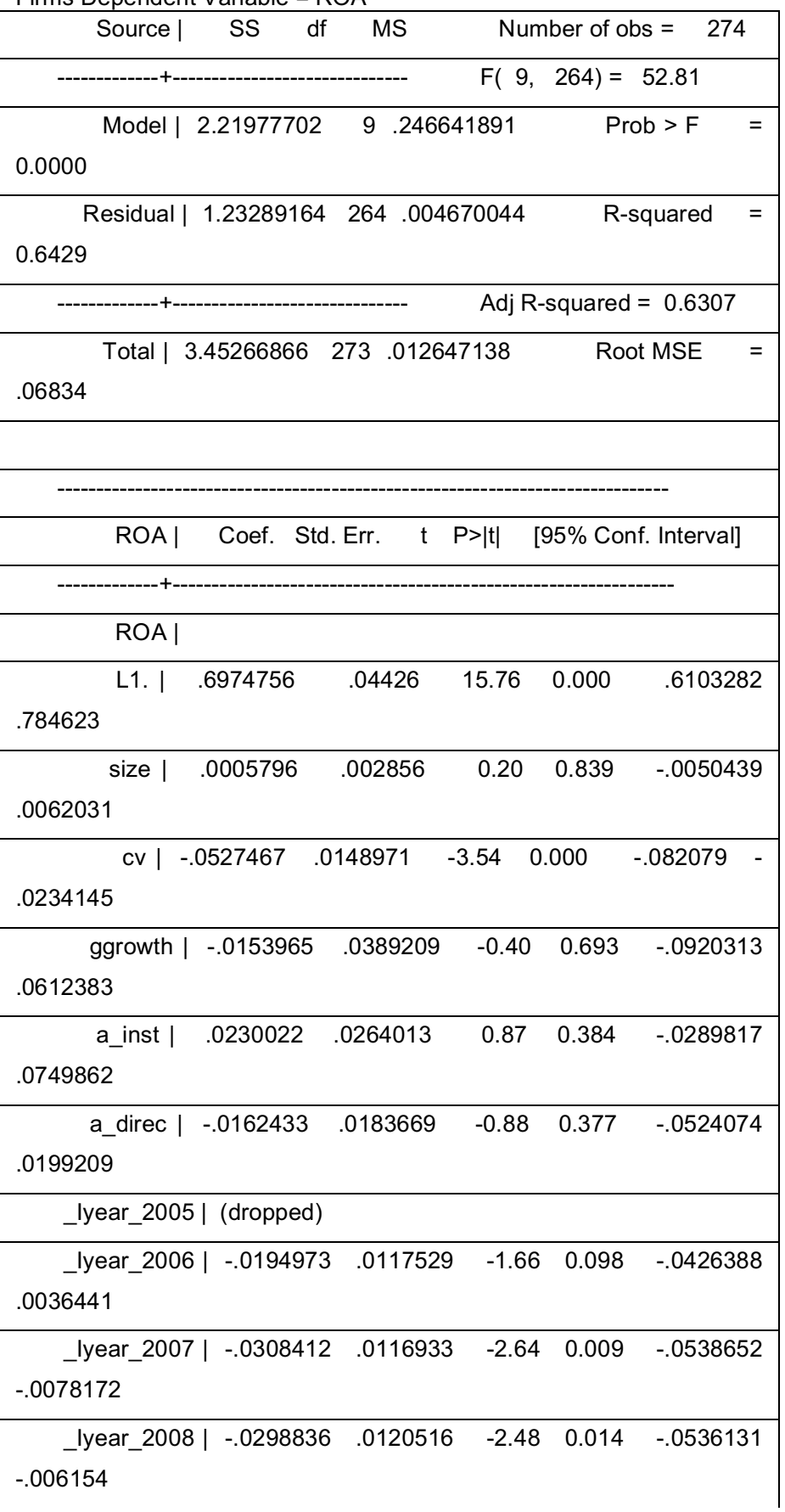




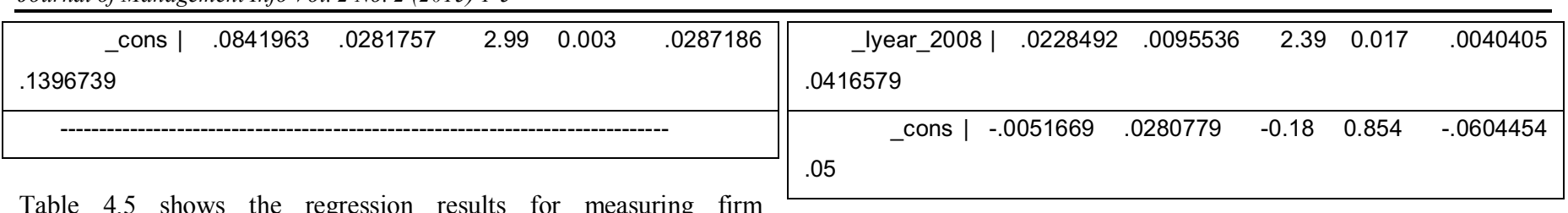
performance for all those firms for which the leverage value is below the median value $(0.629)$ for the dependent variable ROA. There are 274 no. of observations with F-value below 0.05 which shows that the model is overall significant and its R-squared values shows that there are about $64 \%$ chances that the dependent variables is effected by the independent variables under study. The director ownership have negative coefficient values with ROA, while institutional investors have positive value but both are statistically insignificant with their Pvalues greater than 0.05 . These studies also reported no significant results (Demstz and Lehn, 1985; Kamerschen, 1968). The $\mathrm{p}$ value for the time dummies is less than 0.05 which indicates that the intercept of the year 2005, 2006, 2007 and 2008 are significantly different than that of the reference year.

Table 4.6: Regression Results for Firm Performance in Highly Levered Firms Dependent Variable $=$ ROA

\begin{tabular}{|c|c|c|c|c|c|}
\hline Source | & SS df & MS & \multicolumn{3}{|c|}{ Number of obs $=281$} \\
\hline \multicolumn{6}{|c|}{ - } \\
\hline \multicolumn{6}{|l|}{0.0000} \\
\hline $\begin{array}{l}\text { Residual | } \\
0.6600\end{array}$ & 382205531 & 271.0 & & R-square & $\mathrm{d}$ \\
\hline
\end{tabular}

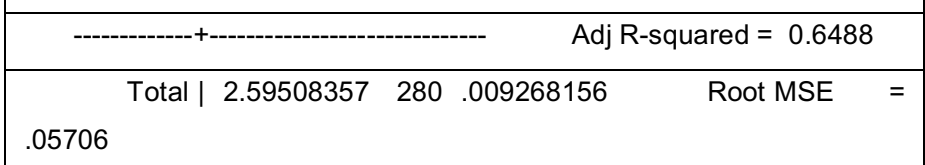

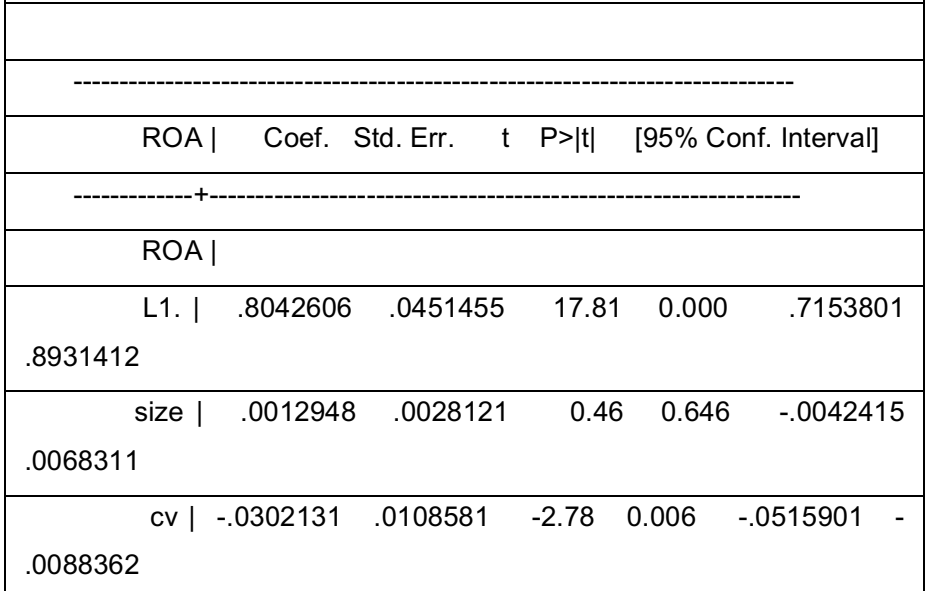

\begin{tabular}{|cccccc|}
\hline $\begin{array}{c}\text { ggrowth | } \\
.0808346\end{array}$ & .0164893 & .0326832 & 0.50 & 0.614 & -.0478561 \\
\hline $\begin{array}{c}\text { a_inst | } \\
.0536727\end{array}$ & .0094301 & .0224724 & 0.42 & 0.675 & -.0348126 \\
\hline $\begin{array}{c}\text { a_direc | } \\
.0198014\end{array}$ & -.010216 & .0152469 & -0.67 & 0.503 & -.0402334 \\
\hline $\begin{array}{c}\text { _lyear_2005 | } \\
\text {.0484955 }\end{array}$ & .0288798 & .0099635 & 2.90 & 0.004 & .0092641 \\
\hline $\begin{array}{c}\text { _lyear_2006 | } \\
\text {.0562689 }\end{array}$ & .0370244 & .009775 & 3.79 & 0.000 & .0177799 \\
\hline _lyear_2007 | (dropped) & & & & \\
\hline
\end{tabular}

Table 4.6 shows the regression results for measuring firm performance for all those firms for which the leverage value is above the median value $(0.629)$ for the dependent variable ROA. There are 281 no of observations with F-value below 0.05 which shows that the model is overall significant and its R-squared values shows that there are about $66 \%$ chances that the dependent variables are affected by the independent variables under study. The institutional ownership have positive coefficient value with ROA, while director shareholding has negative coefficient value but both statistically insignificant with their P-values greater than 0.05. Some studies reported a weak or no statistical relationship between the performance of the firm and the capital structure (Ebaid, 2009; Tang and Jang, 2007). The p value for the time dummies is less than 0.05 which indicates that the intercept of the year 2005, 2006, 2007 and 2008 are significantly different than that of the reference year.

\section{Conclusions}

The current study is carried out to measure the relationship between the capital structure, managerial and institutional ownership and performance of the firm. The study uses two performance measures i.e. market based performance measure, the Tobin's $\mathrm{Q}$ and the accounting-based performance measure, the return on assets (ROA), both as the dependent variables and the independent variables include the ownership proxies and other control variables, whereas leverage is used as moderating variable. The ownership proxies include the managerial ownership and institutional ownership while the control variables include the size of the firm, the coefficient of variation, and growth. This study has used simple regression analysis while using data of 355 firms listed on Karachi Stock Exchange (KSE) for 06 years i.e. 2003 to 2008.

The results indicate that the ownership structure has significant but negative relationship with the market-based performance measure at both low level of leverage and high level of leverage. On the other hand, it has insignificant relationship with the accounting-based performance measure at both low level and high level of leverage. The results are same at both low and high level of leverage, which indicates that the leverage has no moderating effect on the relationship of ownership structure and firm performance of the companies listed on the KSE.

\section{References}

Amjed, S. (2011). Impact of financial structure on firm's Performance: A study of Pakistan's Chemical Sector. Society of Interdisciplinary Business Research (SIBR) 2011 Conference on Interdisciplinary Business Research.

Arbabiyan, Ali-Akbar \& Safari, M. (2009). The effects of capital structure and profitability in the listed firms in Tehran Stock Exchange. Journal of Management Perspective, 33, 159-175.

Berger, A., \& E. Bonaccorsi di Patti. (2006). Capital structure and firm performance: a new approach to testing agency theory and an application to the banking industry. Journal of Banking and Finance, 30, 1065-102.

Berger at el. (2006). Capital structure and firm performance: A new approach to testing agency theory and an application to the banking industry. Journal of Banking \& Finance, 30, 4, 1065-1102.

Berle, A. A., \& G. C. Means. (1932). The modern corporation and private property. New York: Harcourt, Brace and World.

Booth, L., Aivazian, V., Hunt, A., \& Maksimovic, D. (2001). Capital structure in developing countries. Journal of Finance, 56, 87-130.

Chakraborty, I. (2010). Capital structure in an emerging stock market: The case of India. Research in International Business and Finance, 24, 295314.

Driffield N., V. Mahambare, \& S. Pal. (2006). How does ownership structure affect capital structure and firm performance? Recent Evidence from East Asia. Working paper Brunel University, UK. 
Demsetz, H. (1983). The structure of ownership and the theory of the firm. Journal of Law and Economics, 26, 375-390.

Fama, E. F., \& M.C. Jensen. (1983). Separation of ownership and control. JL \& Econ, 26, 301.

Fama, E., \& R. K. French. (2002). Testing trade off and pecking order predictions about dividends and debt. The review of financial studies, 15 , $1,1-33$.

Friend, I., \& L. Lang. (1988). An empirical test of the impact of managerial self-interest on corporate capital structure. Journal of Finance, 43, 271-81.

Huang, S., \& F. Song. (2006). The determinants of capital structure: evidence from China. China Economic Review, 17, 1, 14-36.

Hirshleifer, J. (1966). Investment decision under uncertainty: Applications of the state preference approach. The Quarterly Journal of Economics, 80, 2, 252.

Jensen, M. C., \& W. H. Meckling. (1976). Theory of the firm: Managerial behavior, agency costs and ownership structure. Journal of financial economics, 3, 4, 305-360.

Jensen, M. C. (1986). Agency costs of free cash flow, corporate finance, and takeovers. The American Economic Review, 76, 2, 323-329.

Karadeniz, E., Y. S. Kandir., M. Balcilar. \& B. Y. Onal. (2009). Determinants of capital structure: evidence from Turkish lodging companies. International Journal of Contemporary Hospitality Management, 21, 5, 594-609.

Khan, A. G. (2012). The relationship of capital structure decisions with firm performance: A study of the engineering sector of Pakistan. International Journal of Accounting and Financial Reporting, 2, 1, 2162-3082.

La Porta, R., Lopez de Lilanes, F., \& A. Shleifer. (2000). Agency problems and dividend policies around the world. Journal of Finance, 56, 1, 1-33.

McConnel, J. J., \& H. Servaes. (1995). Equity ownership and two faces of debt. Journal of Financial Economics, 39, 131-157.

Modigliani, F., \& M. Miller. (1958). The cost of capital, corporate finance and the theory of investment. American Economic Review, 48, 261-97.

Modigliani, F., \& M. Miller. (1963). Corporate income taxes and the cost of capital: a correction. American Economic Review, 53, 443-53.

Margaritis, D., \& M. Psillaki. (2010). Capital structure, equity ownership and firm performance. Journal of Banking \& Finance, 34, 3, 621-632.

Mehran, H. (1995). Executive compensation structure, ownership, and firm performance. Journal of Financial Economics, 38, 163-184.

Morck, R., A. Shleifer, \& R. W. Vishny. (1988). Management ownership and market valuation: An empirical analysis. Journal of financial Economics, 20, 293-315.
Myers, S. (1984). The capital structure puzzle. Journal of Finance, 39, 575592.

Memon. F., N. A. Bhutto., \& G. Abbas. (2012). Capital Structure and Firm Performance: A Case of Textile Sector of Pakistan. Asian Journal of Business and Management Sciences, 1, 9, 09-15.

Razak, N. H. A., R. Ahmad., \& H. J. Aliahmed. (2008). Government ownership and performance: An analysis of listed companies in Malaysia. Corporate Ownership and Control, 6, 2, 434-442.

Rajan, R. \& L., Zingales. (1995). What do we know about capital structure? Some evidence from international data. The Journal of Finance, 50, 1421 60 .

Roden, D. \& Lewellen, W. (1995). Corporate capital structure decisions: evidence from leveraged buyouts. Financial Management, 24, 76-87.

Pushner, G. M. (1995). Equity ownership structure, leverage, and productivity: Empirical evidence from Japan. Pacific-Basin Finance Journal, 3, 2-3, 241-255.

Saeedi, A., \& I. Mahmoodi. (2011). Capital Structure and Firm Performance: Evidence from Iranian Companies. International Research Journal of Finance and Economics.

Siddiqui, A. M., \& A. Shoaib. (2011). Measuring performance through capital structure: Evidence from banking sector of Pakistan. African Journal of Business Management, 5, 5, 1871-1879.

Shah, A., \& S. A. Khan. (2009). Empirical investigation of debt-maturity structure: Evidence from Pakistan. The Pakistan Development Review, 48, 4,565-578

Tang, C. H., \& S. S., Jang. (2007). Revisit to the determinants of capital structure: a comparison between lodging firms and software firms. International Journal of Hospitality Management, 26, 1, 175-87.

Tian, G. G., \& R. Zeitun. (2007). Capital structure and corporate performance: evidence from Jordan. Australian Accounting Business and Finance Journal, $1,4$.

Zubairi, H. J. (2010). Impact of Working Capital management and capital structure on profitability of automobile firms in Pakistan. Finance and Corporate Governance Conference 2011 Paper. 